\title{
Sustainable Conservation of The Submerged Historic City of Heracleion, Alexandria, Egypt
}

\author{
Assoc.Prof. Ayman Abd El- Tawab, Dr. Wesam Mehanna, and Fatma Alashwah \\ Architectural Engineering Department, Faculty of Engineering, \\ Tanta University, Egypt
}

\begin{abstract}
The seabed is considered as the biggest museum in the world that is rich with unique shapes of underwater cultural heritage. Over years, entire cities have been swallowed by the waves in Alexandria. Heracleion was the main Egyptian trading centre, which was completely submerged 2700 years ago in the western part of Abo Qir bay. Recently, the quick urban and coastal development in abo Qir raises numerous critical urban issues, which need tending to secure the urban development while ensuring sustainable conservation of the submerged city of Heracleion. The main objective of the research is to provide long term of the conservation measures for this unique city and its waterfront for future generation. This study suggests a framework for applying sustainable conservation, by respecting the economic, social, environmental, and urban dimensions of the submerged city and its waterfront. Furthermore, this study investigates the community perception for the proposed conservation projects in achieving the sustainable development through a questionnaire.
\end{abstract}

Keywords: submerged city, sustainable conservation, Heracleion, waterfront.

\section{INTRODUCTION}

Underwater cultural heritage $(\mathrm{UCH})$ is defined as: "all traces of human existence having a cultural, historical or archaeological character, which have been partially or totally under water, periodically or continuously, for at least 100 years" [1, p.152]. It can be classified into wrecks, submerged structures, and submerged landscape (Fig.1).

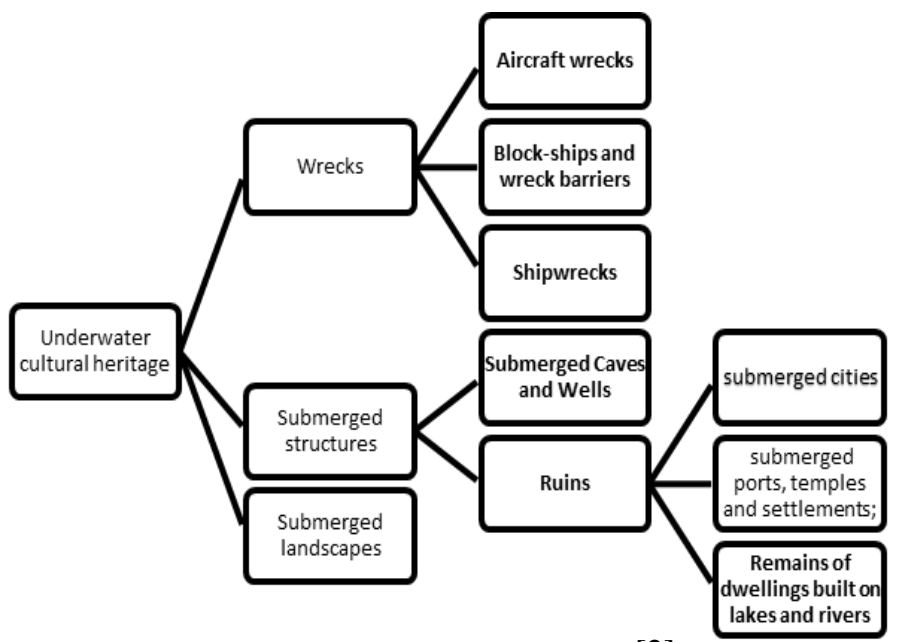

Figure1.The underwater cultural heritage classification [2].

By 2100 , more than 15 cities may be submerged, and the current submerged heritage may be damaged, which may effect on the economic, social, and cultural behaviors of the communities. Moreover, the urban image of the cities will be changed [3, p.842].

Heracleion is one of the cities that have been submerged in the Mediterranean Sea [4]. The field survey and the interviews with (UCH) experts show that over years the submarine environment safely preserved the city underwater. Today, the submerged city and its waterfront in Abo Qir face social, environmental, economic, urban risks, and negative impacts that endanger its conservation. Furthermore, most of the conservation efforts are focused on the archaeological side with the absence of an architect role in the conservation and development planning process. Therefore, sustainable conservation strategies are needed to improve the economic, social, environmental, and urban conditions for the conservation of this unique form of cultural heritage for the benefit of the current and future generations.

\section{THE THEORETICAL STUDIES}

\section{SUSTAINABLE CONSERVATION OF THE SUBMERGED} CITIES

The concept of sustainable conservation has been developed as a result of the growing influence of the sustainable development concept on all aspects of life [5, p.160]. Sustainability can be used to achieve heritage conservation. The basic concept of sustainability is to use what already exists and the basic concept of conservation is to protect what we already have [6, p.220,230]. Sustainable conservation of the submerged cities can be identified as all process of care and treatment of movable and immovable objects in the submerged city to ensure that future generations inherit a world at least as bountiful as the present generations inhabit. In addition, it involves treating the waterfront as a zone of urban development and the dynamic interactions between submerged city and the waterfront urban fabric [7, p.135].

This concept deals with many aspects, such as the multifunctional use of the urban fabrics of the submerged city waterfront, harmony of socioeconomic, environmental aspects of the urban waterfront of submerged city with its residents, conservation of the terrestrial heritage buildings, and linking them with the submerged city. Moreover, these aspects consider the possible techniques to provide a long term of the sustainable conservation measures of the submerged cities [8, p.66-67].

\section{THE SUBMERGED CITY OF HERACLEION}

Heracleion was founded around the 8th century BC, before establishing the city of Alexandria. It was located near the Canopus branch of the Nile [9]. Today, the submerged city lies in Abo Qir bay water in depths of 5-8 m,15 miles north-east of Alexandria, and covers an area about $600000 \mathrm{~m}^{2}$ [10.11, p.5] (Fig.2). 


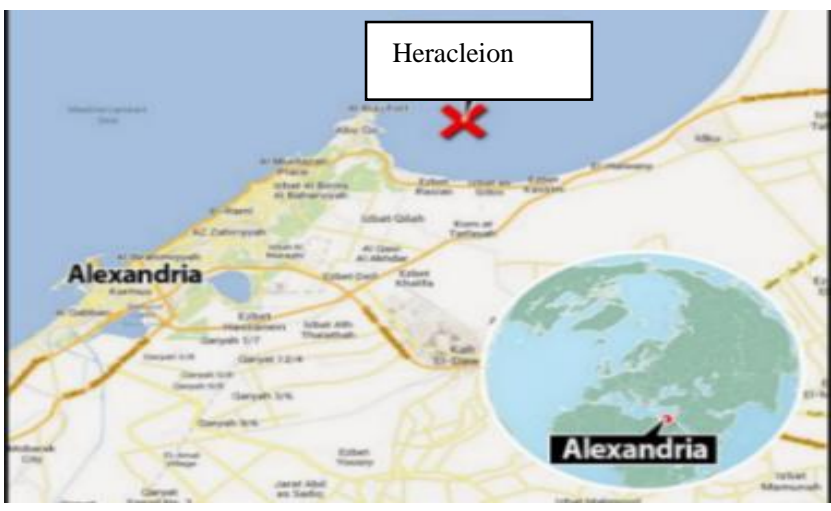

Figure 2. Heracleion location in Alexandria [12].

Abo Qir is connected locally through two main lines; , and Alexandria-Rosetta road. Besides, it is connected internationally through the coastal road, which links all the northern Mediterranean cities [13, p.7-8] (Fig.3). Furthermore, Heracleion and its waterfront in Abo Qir have unique values that is analysed as follow in Table. 1

To the coastal road (International Road)

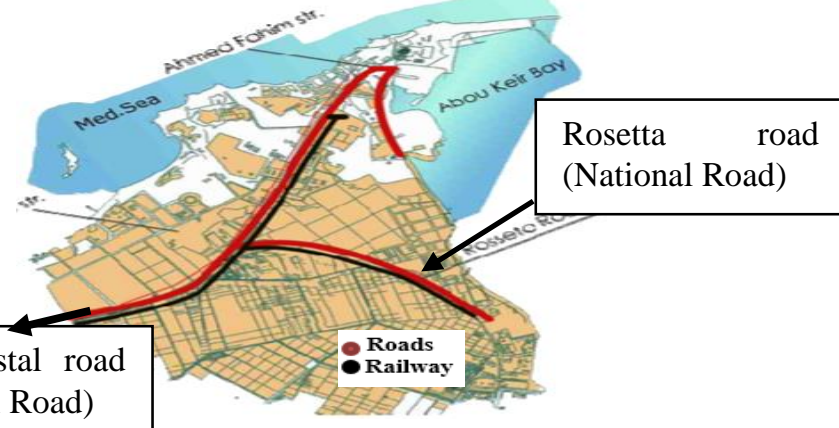

Figure 3. Abo Qir accessibility [13].

\section{THE METHODOLOGY OF THE SUSTAINABLE CONSERVATION OF THE SUBMERGED CITIES}

This methodology of this research based on reviewing the future comprehensive planning for the development strategy of Abo Qir, including site visits, observations, interviews with consulting experts of urban planning, and $\mathrm{UCH}$ conservation. This methodology is constituted by six sequential stages that planning proposals for sustainable conservation of the submerged historical cities as follows:

- Stage one: primary studies that included an overview of the submerged city, and its relation with the context.

- Stage two: studies on the submerged city and its waterfront that included reference situation analysis, environmental, economic, social, and urban analysis.

- Stage three: S.W.O.T that involved the recognition of the local strengths, weaknesses, threats, and the opportunities.

- Stage four: it aimed to identify the strategies of the sustainable conservation. Furthermore, it evaluated the proposed strategies through a questionnaire.

- Stage five: it included the formulation of the plan design.

- Stage six: it involved the design of the implementation technical sheets, and the evaluation processes (Fig.4).
TABLE 1

The values of the study area (Author)

\begin{tabular}{|c|c|c|}
\hline$\frac{\mathscr{d}}{\stackrel{\sigma}{\sigma}}$ & Abo Qir waterfront & The city of Heracleion \\
\hline 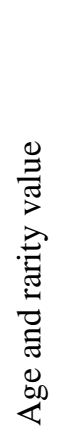 & $\begin{array}{l}\text { It includes important } \\
\text { monuments, such as the } \\
\text { historical church of the } \\
\text { great martyrs Abo Qir } \\
\text { and John, military } \\
\text { buildings and fortress } \\
\text { that were founded in the } \\
\text { Mamluk, Jarks and } \\
\text { Mohamed Ali eras. }\end{array}$ & $\begin{array}{l}\text { The submerged city is } \\
\text { rich with significant } \\
\text { discoveries of the } \\
\text { Egyptian ruins, such as } \\
\text { the goddess Isis, and the } \\
\text { god Hapi that have been } \\
\text { exposed after more than } \\
\text { thousand years beneath } \\
\text { the water of Abo Qir } \\
\text { Bay. }\end{array}$ \\
\hline 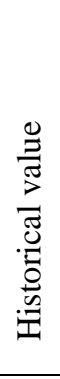 & $\begin{array}{l}\text { The waterfront is rich } \\
\text { with historical events } \\
\text { that have been } \\
\text { transpired there, such as } \\
\text { the Battle of the Nile } \\
\text { that considered one of } \\
\text { the greatest victories of } \\
\text { Horatio Nelson on the } \\
\text { French fleet in } 1798 \text {. }\end{array}$ & $\begin{array}{l}\text { Heracleion have been } \\
\text { associated with } \\
\text { significant historical } \\
\text { events. It is considered } \\
\text { as the main Egyptian } \\
\text { port during the time of } \\
\text { the later pharaohs. }\end{array}$ \\
\hline 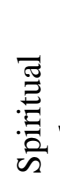 & $\begin{array}{l}\text { The church of John } \\
\text { Coptic Orthodox is } \\
\text { used as a historical } \\
\text { place of worship. }\end{array}$ & $\begin{array}{l}\text { The city's temple of } \\
\text { Amun has been } \\
\text { associated with dynasty } \\
\text { continuity. }\end{array}$ \\
\hline 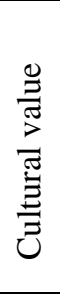 & $\begin{array}{l}\text { The cultural heritage } \\
\text { sites, such as } \\
\text { Fortresses, and the } \\
\text { archaeological } \\
\text { discoveries are used to } \\
\text { build cultural affiliation } \\
\text { for society. }\end{array}$ & $\begin{array}{l}\text { Heracleion underwater } \\
\text { ruins are playing an } \\
\text { important role in } \\
\text { reconnecting } \\
\text { community with their } \\
\text { cultural, marine and } \\
\text { natural environment. }\end{array}$ \\
\hline 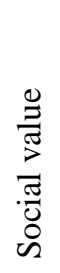 & $\begin{array}{l}\text { The public-space in } \\
\text { the waterfront is used as } \\
\text { spaces for social } \\
\text { gatherings, such as } \\
\text { celebrations, markets, } \\
\text { and picnics. }\end{array}$ & $\begin{array}{l}\text { It is used as a unique } \\
\text { site for diving, and } \\
\text { heritage tourism. }\end{array}$ \\
\hline 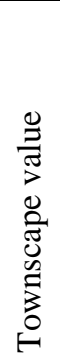 & $\begin{array}{l}\text { It shapes a triangular } \\
\text { peninsula that extends } \\
\text { into the Mediterranean } \\
\text { Sea. The streets have } \\
\text { visual ends overlooking } \\
\text { the sea that } \\
\text { characterizes Abo Qir } \\
\text { with unique identity. }\end{array}$ & $\begin{array}{l}\text { It had a unique urban } \\
\text { planning form that } \\
\text { resembled Venice, Italy, } \\
\text { with its intricate network } \\
\text { of canals. }\end{array}$ \\
\hline
\end{tabular}



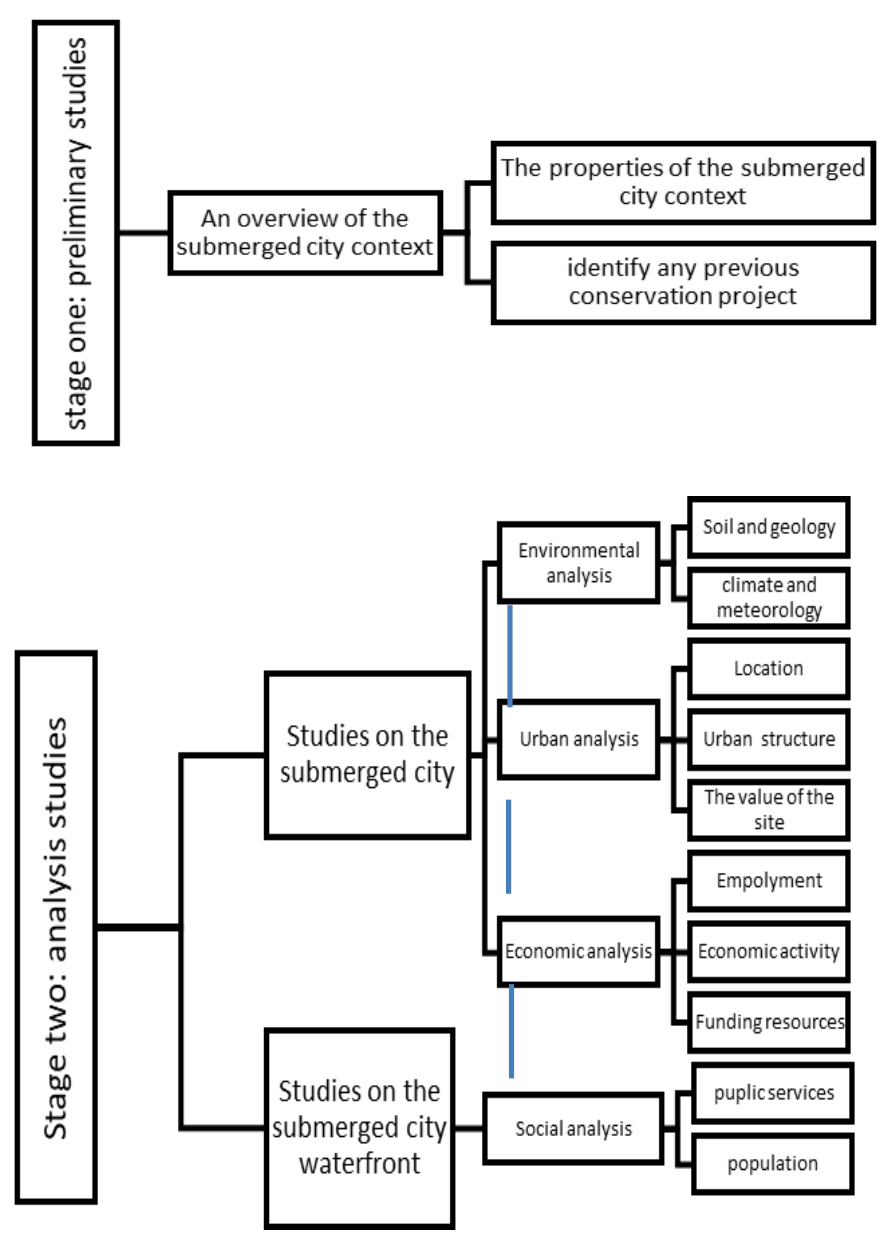

Stage three: (S.W.O.T) the definition of operative criteria of intervention.

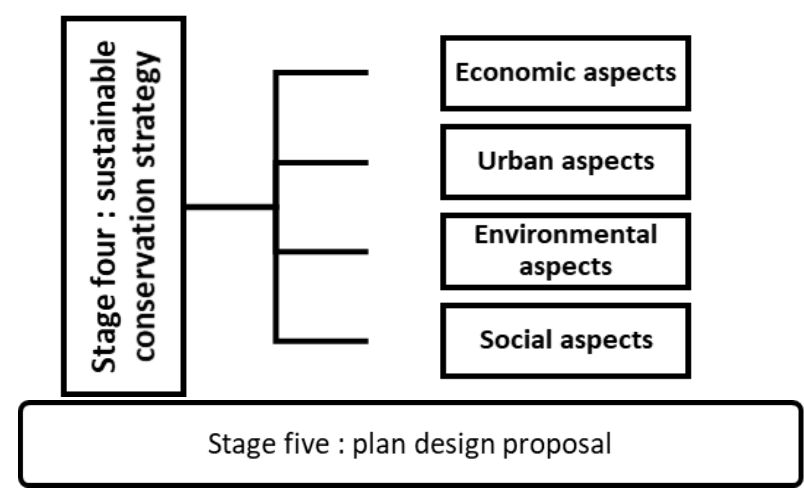

Stage six:implementation and evaluation process

Figure 4. The methodology of the sustainable conservation of the submerged cities (Author).

\section{STAGE ONE: PRELIMINARY STUDIES}

Alexandria was founded in 330 B.C. It lies on the Mediterranean coast at the western edge of the Nile Delta $[14$, p.174]. Over years, geological factors and sea level -

changes have been played a role in destroying and submerging many monuments of the ancient city in the Mediterranean, such as the submerged sites in the vicinity of the Fort of Qait Bey, the eastern harbour ,Cape Lochias, and the submerged city of Canopus, and Heracleion in Abo Qir Bay [15, p.14] (Fig.5).

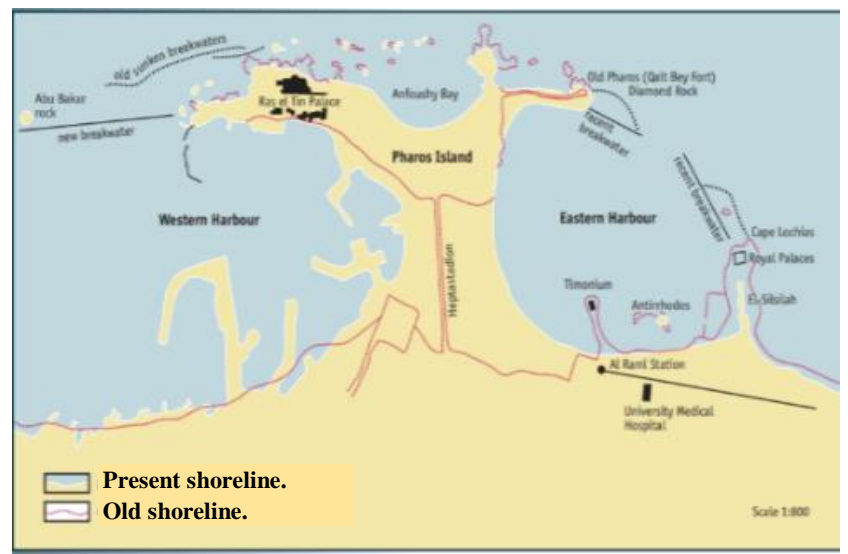

Figure5. Underwater cultural sites in Alexandria [15].

The conservation of Alexandria submerged sites

The department for underwater antiquities (DUA) was founded in 1996 in Alexandria, to be responsible for conserving underwater cultural heritage in Egypt [16, p.199200]. DUA arranges archaeological dives tours to submerged sites from two diving centre in Alexandria. Moreover, the open-air museum of Kom el-Dikka, Qait Bey Fort museum, museum of antiquities of Alexandrina bibliotheca, and the national museum of Alexandria exhibit artefacts from the submerged sites [17, p.227].

In 2008, the UNESCO announced that it would help Egypt in building underwater museum in the Bay of Alexandria. Nevertheless, the project was rejected for many reasons [18].

\section{STAGE TWO: ANALYSIS STUDIES}

The analysis studies are divided into two sections as follow:

3-1- First section: studies on the waterfront of Abo Qir

The study area involves three neighbourhoods, which are Eastern Abo Qir, western Abo Qir, and parts of Mamoura

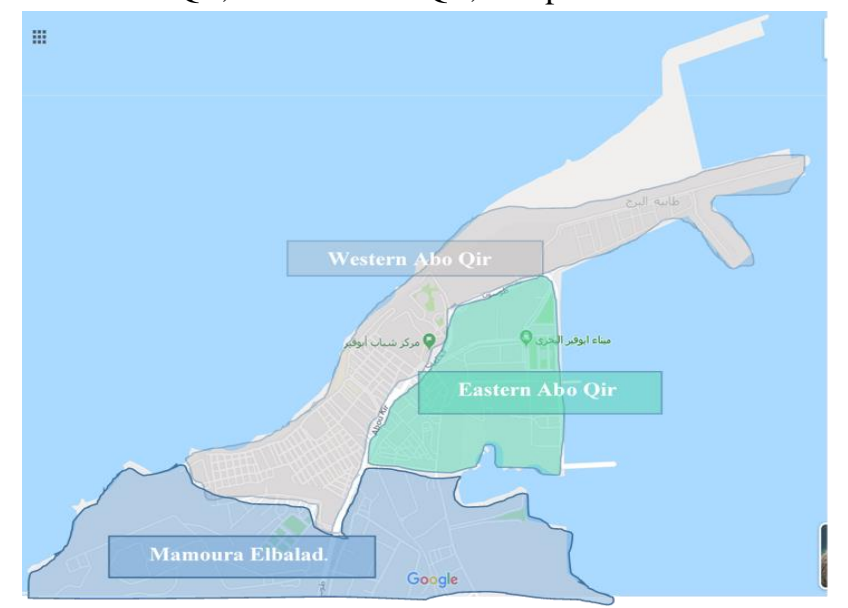

Figure 6. The administrative division of the study area (field survey). 
a. Urban studies

The field survey show that Abo Qir waterfront urban spaces are used for diverse purposes as industrial, commercial, tourism, fishing, shipping, army, and as a repository for sewage effluents [19,p.48] (Fig.7).

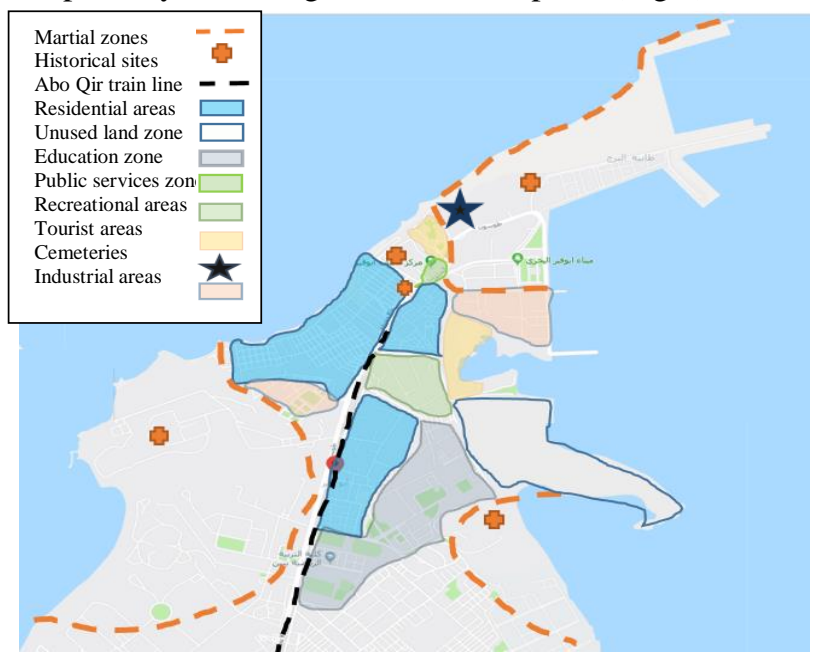

Figure 7. The land use studies (field survey).

Cultural heritage sites: Abo Qir is rich with historical terrestrial sites, such as El Ramel Fort, Kousa Pasha Fort, EL-Twafekia Fort, Abo Qir Fort, Nelson Island, and historical, Church of the great martyrs Abo Qir and John. Furthermore, it contains submerged historical sites, such as canopus submerged city, Herclion submerged city, Nelson Island submerged ruins, and the sunken Napoleon fleet (Fig.8).

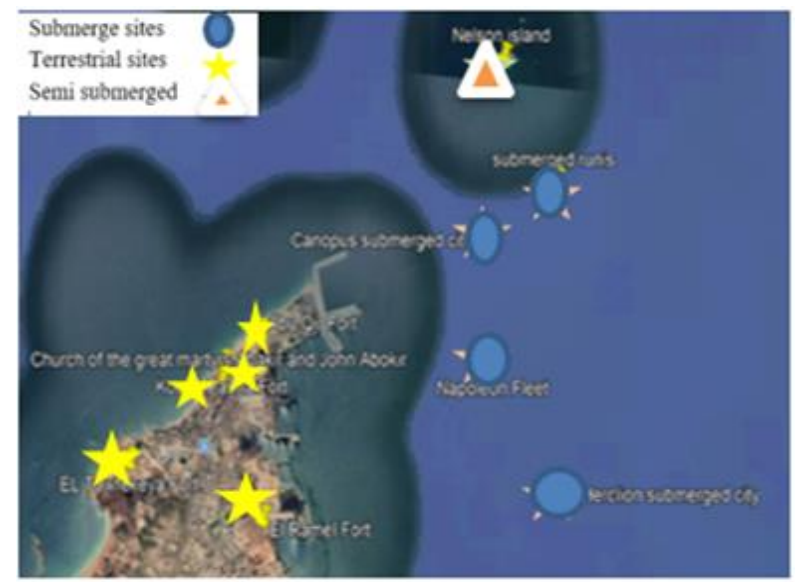

Figure 8. The study area cultural heritage site (Google earth).

b. Social studies

The study area has a population range of 44,530 residents [20], with total number of households 11,897 . As well, the average of household size is 3.8 , and overcrowding rate is 1 , 11 (Fig.9,10) shows the age structure of the residents, and the level of education [21].

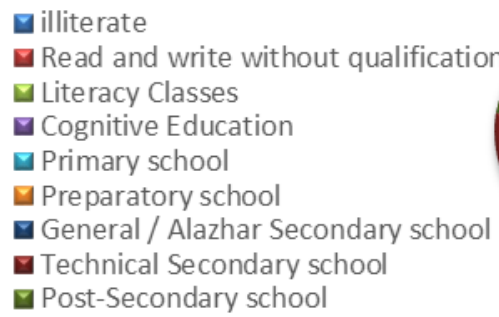

口 Read and write without qualification $\square$ Literacy Classes

- Cognitive Education

Drimary school

$\square$ Preparatory school

- General / Alazhar Secondary school

- Technical Secondary school

Post-Secondary school

Figure 9. The level of education of the study area [21].

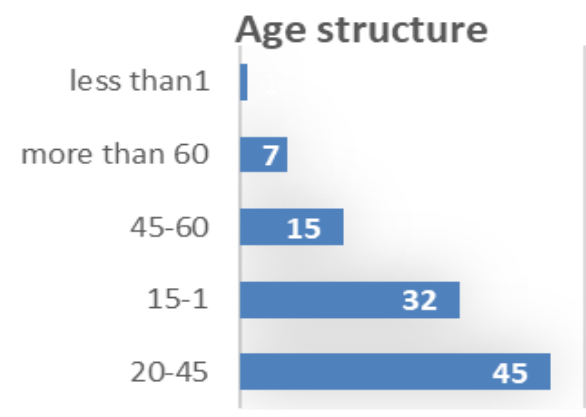

- 20-45 15-1 a 45-60 more than 60 a less than 1

Figure 10. The age structure of the study area [21].

c. Economic studies

The economic activities involve industrial, trading, fishing and public service [22] (Fig.11).

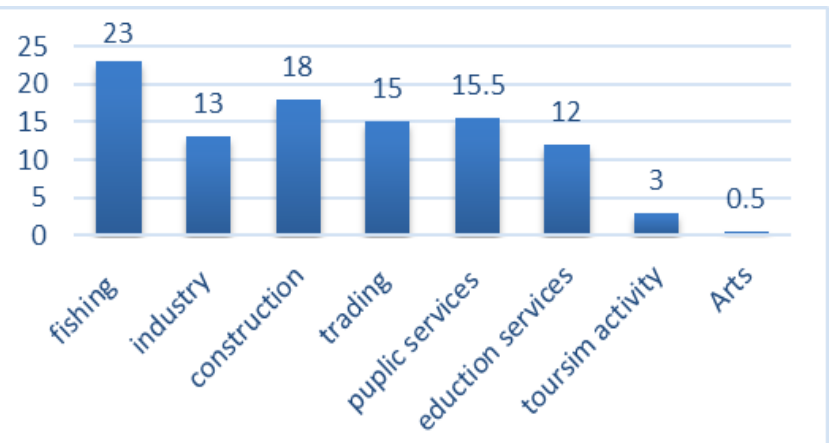

Figure 11. Economic activity sector [22].

\section{d. Environmental studies}

The topography of Abu Qir is almost smooth except some parts in the west [23] (Fig.12). Furthermore, it has an arid climate with a mean annual rainfall of $18.8 \mathrm{~cm}$. Abo Qir is characterized by high relative humidity and a high rate of evaporation. Northerly and north-westerly winds are more predominant than those from the other directions [24, p.1231] (Fig.13).

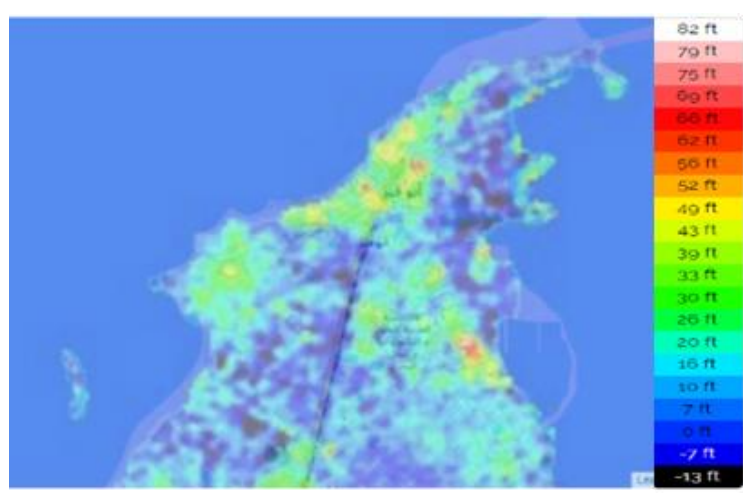

Figure12. Study area topographic [23]

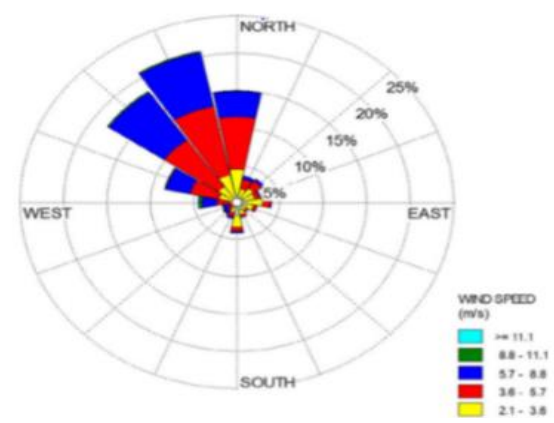

Figure 13. Wind rose over the study area [24] 
3-2-The second section: studies of the submerged city of Heracleion

a. Heracleion historical background

The city was an important Egyptian port and a religious centre. It had been exposed to natural disasters, flooding, earthquake, tsunami, and finally submerged in the Mediterranean Sea in the 8th century [10].

The city was built around its grand temple of Amun due to its religious importance. It was criss-crossed with a network of canals, and the islands were involved small sanctuaries and mudbrick homes [25] (Fig.14).

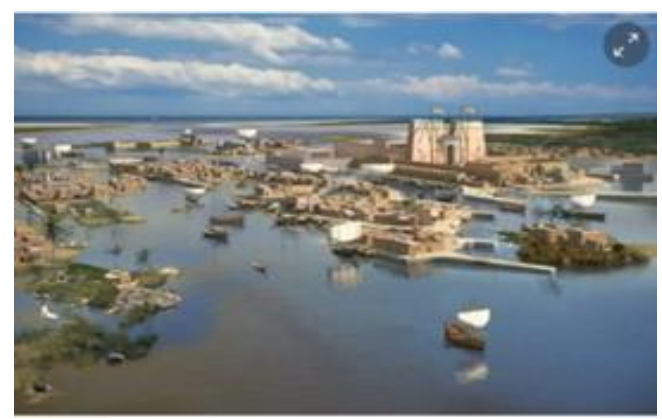

Figure 14. The city of Heracleion [10].

\section{b. Economic studies}

Heraclion contains many treasures, such as the ruins of temples, shards of pottery, precious jewellery, coins, oil lamps, processional barges and busts [26,27]. These ruins have an economic benefit from exhibiting them and the direct sale of the materials about its ruins, such as reproductions, print media, books, video/movie rights and royalties, etc [28, p.181].

\section{c. Environmental studies}

Abo Qir Bay is a shallow semi-circular basin with a total area of about $400 \mathrm{~km}^{2}$ and an average depth of about $16 \mathrm{~m}$. The bay has shorelines of about $50 \mathrm{Km}$. The Rosetta branch of the River Nile is located at the eastern side of Abo Qir Bay [29, p.5].

-Soil and geology

The bed nature of Abo Qir Bay is almost smooth, but there are many rocky subsurface ridges, some extent over the surface to form small islands (Fig.15). Nelson Island is the largest one, which is approximately $5 \mathrm{~km}$ from the shore [24, p.1230-1231].

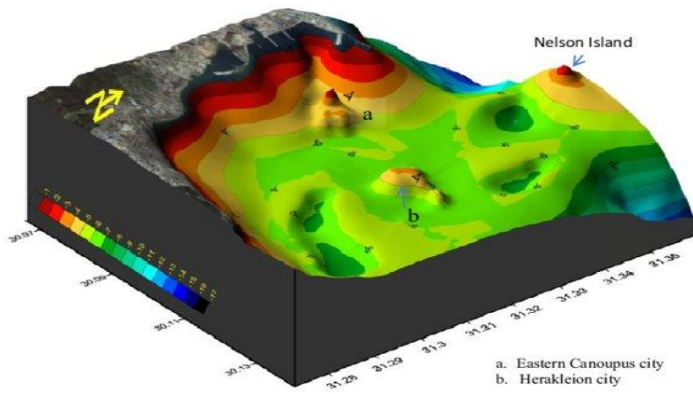

Figure 15. The bed of Abo Qir bay [11, p.4]

Climate and Meteorology: The water temperature varies from $27^{\circ} \mathrm{C}$ and $29^{\circ} \mathrm{C}$ [11, p.1]. The best time in the year for diving in the bay is spring and autumn.

\section{STAGE THREE: S.W.O.T. ANALYSIS FOR STUDY AREA}

After analysing the submerged city of Herclaion and its waterfront. The S.W.O.T are concluded as follows in (Table.2, 3)

TABLE 2

The strength and weakness of the study area (Author).

\begin{tabular}{|c|c|c|}
\hline & Strength & Weakness \\
\hline 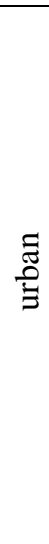 & $\begin{array}{l}\text {-It has a strategic location, it is considers as the } \\
\text { eastern gate to Alexandria. } \\
\text {-Abo Qir waterfront is rich with unique } \\
\text { monumental sites both in water and inland. } \\
\text { - It has an easy Figure 16. Abo Qir } 6 \text { October } \\
\text { access by the public beach (Author). } \\
\text { transport. } \\
\text {-Heracleion is located near significant } \\
\text { submerged ruins in Abo Qir Bay. } \\
\text { - It involves many recreational beaches (Fig.16). } \\
\text {-Abo Qir has a significant history, which playing } \\
\text { an important role in representing the different } \\
\text { historical stages in the city development. }\end{array}$ & $\begin{array}{l}\text { - Abo Qir public transport is unsafe, and poorly maintained } \\
\text { (Fig.17). } \\
\text {-Abo Qir waterfront pedestrian streets are unattractive, and } \\
\text { many streets are inaccessible due to its location in the military } \\
\text { sites. } \\
\text {-Abo Qir has many high illegal buildings on its waterfront. } \\
\text { - Waterfront urban spaces and beaches are suffered from mal } \\
\text { exploitation. } \\
\text { - Abo Qir historic sites face severe threats due to neglect and } \\
\text { deterioration. } \\
\text { - The bay is used for variety of purposes that did not fit with } \\
\text { the region historical value. }\end{array}$ \\
\hline & $\begin{array}{l}\text {-The labor market is characterized by a } \\
\text { relatively high labor force, especially in the } \\
\text { technical fields. } \\
\text {-It has a significant institution, such as Research } \\
\text { Centre, Egyptian Coastguard Forces, Gas and } \\
\text { Petroleum company, the Higher institutes for } \\
\text { tourism, hotels, and all of them have a relation } \\
\text { with submerged sites conservation. }\end{array}$ & $\begin{array}{l}\text {-Abo Qir submerged sites are managed by the Egyptian } \\
\text { Coast Guard Forces, which indicates that the security issues } \\
\text { come over the conservation of the cultural heritage issues. } \\
\text {--Low public awareness constitutes a strong obstacle against } \\
\text { any conservation programme in the region. Many residents in } \\
\text { abo Qir do not even know about their cultural heritage sites } \\
\text { whether on land or underwater. }\end{array}$ \\
\hline
\end{tabular}




\begin{tabular}{|c|c|c|}
\hline$\cdot \frac{\pi}{8}$ & $\begin{array}{l}\text { - Qir residents are deeply rooted within their } \\
\text { area. }\end{array}$ & $\begin{array}{l}\text {-Abo Qir streets, beaches, and waterfront public space suffer } \\
\text { from lacking of the safety due to negative social behaviour } \\
\text { (Fig .18, 19). } \\
\text {-Abo Qir is rich of intangible heritage as the fishermen } \\
\text { traditional dances. } \\
\text {-Abo Qir district is organized meetings with the local residents. }\end{array}$ \\
\hline 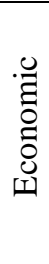 & $\begin{array}{l}\text {-The coastal zone hosts significant ecological } \\
\text { habitats, economic centres and agricultural } \\
\text { resources. } \\
\text {-The waterfront is rich with economic activities, } \\
\text { such as fishing, tourism, industrial, and } \\
\text { commercial. }\end{array}$ & $\begin{array}{l}\text {-The conservation process are very expensive, especially under } \\
\text { the current economic conditions. }\end{array}$ \\
\hline 苞 & $\begin{array}{l}\text {-It has a unique geographical position. } \\
\text {-Eco materials are used in construction in the } \\
\text { waterfront (Fig.20) } \\
\text { - Horse carts are used as a sustainable mode of } \\
\text { transport to access the waterfront. (Fig.21) }\end{array}$ & $\begin{array}{l}\text { - Abo Qir bay suffers from pollution that have a negative effect } \\
\text { on public health, and submerged sites (Fig .22) } \\
\text { - Inefficiency use of the renewable energy sources as the solar, } \\
\text { wind, and the tidal energy. } \\
\text { - Many sources of pollution have been defined in the study } \\
\text { area, such as solid waste, and noise, (Fig.23). } \\
\text { - Abo Qir has many areas with no supply of drainage pipes. } \\
\text { - Abo Qir is suffered from air pollution from different } \\
\text { industrial factories. }\end{array}$ \\
\hline
\end{tabular}

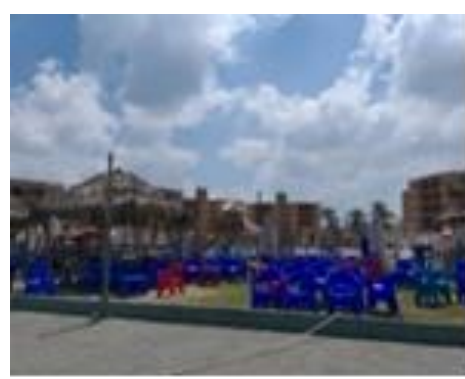

Figure 16. Abo Qir 6 October beach (Author).

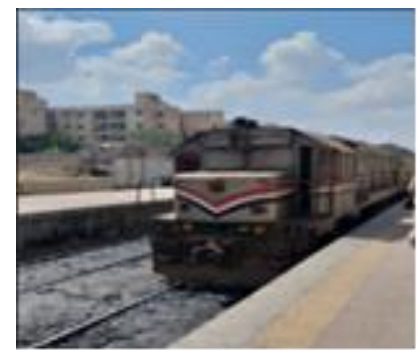

Figure 17. Abo Qir train lines (Author).

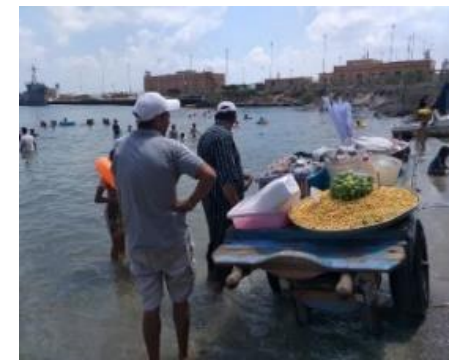

Figure 18. Absence of safety on beaches (Author).

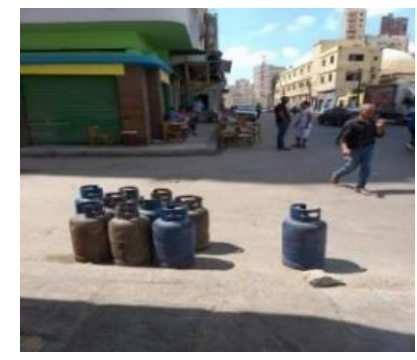

Figure 19. Gas container on the waterfront's street (Author).

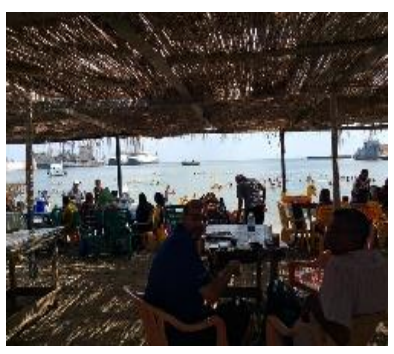

Figure 20. Using Eco materials (Author)

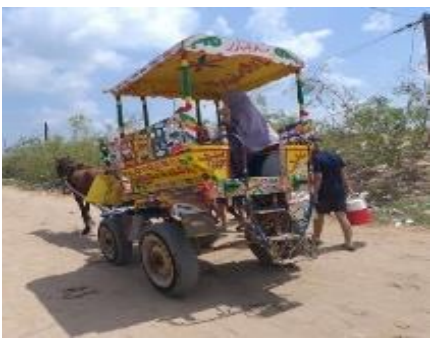

Figure 21. Horse carts (Author).

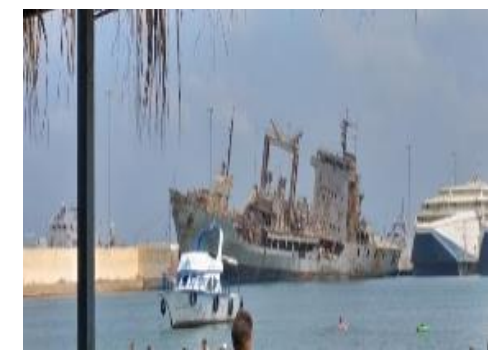

Figure 22. Marine wastes in the Abo Qir bay (Author).

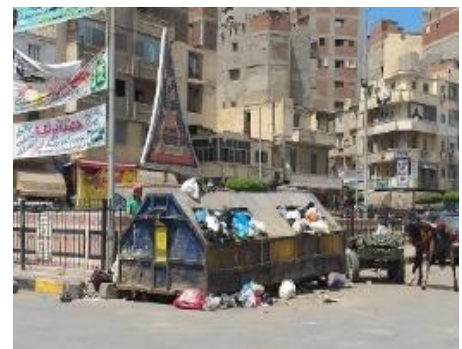

Figure 23. Solid waste collection (Author). 
The threats and opportunities of the study area (Author).

\begin{tabular}{|c|c|c|}
\hline & Threats & Opportunities \\
\hline 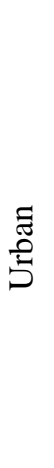 & $\begin{array}{l}\text { - The submerged sites in Abo Qir bay are } \\
\text { in risk of disappearance. } \\
\text {-Alexandria's strategic plan } 2032 \text { neglects } \\
\text { the submerged and historic sites in Abo Qir. }\end{array}$ & $\begin{array}{l}\text { - Chance to link the submerge city with other historical heritage } \\
\text { sites in Alexandria. } \\
\text {-The bay can be used for a variety of purposes, such as } \\
\text { commercial and recreational fishing, recreational boating, yachting, } \\
\text { swimming and diving to explore sunken monuments. } \\
\text {-It includes many motives for development: a waterfront with } \\
\text { many brownfields, unplanned open spaces, historical sites and } \\
\text { submerged treasures. } \\
\text {-Different mean of transportation, such as boats, cars, buses and } \\
\text { horse cars are used to access the waterfront. } \\
\text {-Abo Qir train will be converted to an attractive electric metro. }\end{array}$ \\
\hline 丞 & $\begin{array}{l}\text {-The rapid population growth posed an } \\
\text { obstacle for the conservation programme. } \\
\text { [15]. } \\
\text {-In Egypt, there is no national } \\
\text { legalization specified for underwater } \\
\text { cultural heritage [32]. }\end{array}$ & $\begin{array}{l}\text {-The interest to the underwater cultural tourism has been } \\
\text { increasing in world scale. } \\
\text {-Abo Qir residents are ready to cooperate with the decision } \\
\text { makers in the conservation measures. } \\
\text {-Different organization, such as Research centre, Egyptian } \\
\text { Coastguard Forces, Gas and Petroleum company, and the Higher } \\
\text { Institutes for Tourism and Hotels can be cooperated to provide a } \\
\text { long term of the sustainable conservation measures for submerged } \\
\text { city. } \\
\text {-Chance to create highly attractive waterside locations, which } \\
\text { provide public access to submerged city. }\end{array}$ \\
\hline 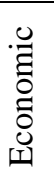 & $\begin{array}{l}\text {-The industrials activities in the } \\
\text { waterfront have a destructive effect on the } \\
\text { cultural heritage sites. }\end{array}$ & $\begin{array}{l}\text {-Chance to create local jobs that base on the submerged city } \\
\text { conservation measures. } \\
\text { - The site contains high tourism potentials, which influence on the } \\
\text { Egyptian economy. }\end{array}$ \\
\hline 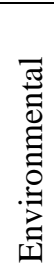 & $\begin{array}{l}\text {-The coastline is in peril of coastal } \\
\text { erosion, earthquakes, flooding and sea level } \\
\text { rise. } \\
\text {-The submerged city and its waterfront } \\
\text { are in risk of damage due to storms with } \\
\text { spring tides (high tides) [28]. }\end{array}$ & $\begin{array}{l}\text { - The site is considered as an important attraction point due to its } \\
\text { location nationally and internationally. } \\
\text { - Abo Qir bay is considered as a fertile marine habitat. }\end{array}$ \\
\hline
\end{tabular}

2. Stage four: it involves the sustainable conservation strategies (Table.4).

TABLE 4

The sustainable conservation strategies (Author).

\begin{tabular}{|c|l|l|}
\hline The Strategies & The tool \\
\hline $\begin{array}{l}\text {-Conservation of underwater and } \\
\text { terrestrial heritage; } \\
\text {-Development of the submerged city } \\
\text { waterfront urban spaces; } \\
\text {-Linking submerged city waterfronts } \\
\text { with the urban city fabric and terrestrial } \\
\text { heritage sites; }\end{array}$ & $\begin{array}{l}\text {-Establishment of touristic trails between different interesting points } \\
\text { as the historical Fortes, historical Church of the great martyrs Abakir } \\
\text { and John, fish market, Herclion city, Canopus city, Nelson island } \\
\text { submerged ruins, Napoleon fleet, and Montaza submerged ruins; } \\
\text {-Providing the aesthetic, function, and safety standards in the } \\
\text { development of the waterfronts public access, walkways, nodes, open } \\
\text { spaces, and land use patterns; } \\
\text {-Preservation, maintenance, and adaptation of Abo Qir terrestrial } \\
\text { heritage building; } \\
\text {-Using relocating, reburial, and built heritage approach } \\
\text { In the conservation of the submerged sites in Abo Qir; }\end{array}$ \\
& \\
\end{tabular}




\begin{tabular}{|c|c|c|}
\hline 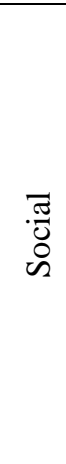 & $\begin{array}{l}\text {-Participation of the stakeholders in } \\
\text { the sustainable conservation activities; } \\
\text {-Providing public awareness in } \\
\text { conservation cultural heritage; } \\
\text {-Conservation of local and national } \\
\text { identities; } \\
\text {-Enrich the cultural offer of the } \\
\text { historical place; }\end{array}$ & $\begin{array}{l}\text {-Involving the stakeholders as Abo Qir residential, Egyptian } \\
\text { Coastguard Forces, and diving community in the conservation activates, } \\
\text { through organized workshops, and meetings that is held in Abo Qir youth } \\
\text { camp and center; } \\
\text {-Training the local community for terrestrial and underwater heritage } \\
\text { conservation work and tour guiding in cooperation with the Higher } \\
\text { institutes for Tourism and Hotels in Abo Qir; } \\
\text {-Resurgence of historical events in Abo Qir history in authentic } \\
\text { locations; } \\
\text {-Providing public access to the submerged sites for divers and non- } \\
\text { divers community; }\end{array}$ \\
\hline 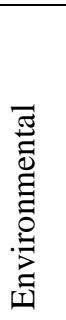 & $\begin{array}{l}\text {-Securing the quality of water and } \\
\text { the environment; } \\
\text {-Preserving marine life and birds; }\end{array}$ & $\begin{array}{l}\text {-Treatment Abo Qir bay water from sewage and industrial wastes; } \\
\text {-Improving abo Qir infrastructure by cooperation with stakeholders } \\
\text { and Alexandria government; } \\
\text {-Adoption of the sustainable design approach for the design of } \\
\text { buildings and public spaces in Abo Qir waterfront; } \\
\text {-Designing eco parks in waterfront area, and using landscape elements } \\
\text { to resistant, the coastal erosion; }\end{array}$ \\
\hline 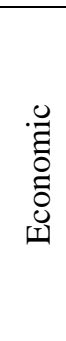 & $\begin{array}{l}\text {-Providing economic growth that } \\
\text { depending on cultural heritage } \\
\text { conservation activities; } \\
\text {-Providing sustainable tourism } \\
\text { industry; } \\
\text { - Provision youth employment; } \\
\text {-Poverty reduction and social } \\
\text { justice; }\end{array}$ & $\begin{array}{l}\text {-Development of tourism economic activities along the submerged city } \\
\text { waterfront through pairing of land and underwater sites in cultural routes, } \\
\text { museums or eco-tours; } \\
\text {-Employing the local community in the conservation projects; } \\
\text {-Establish practical financial strategies through cooperation between } \\
\text { funding organizations, public and private sectors; }\end{array}$ \\
\hline
\end{tabular}

\section{THE PROPOSED FRAMEWORK}

a. The urban vision

The first stage is concerned with opening the coastal archaeological sites and preparing a schedule of visits to the submerged heritage sites and Nelson Island, in accordance with stakeholders meeting. This stage aims to bring people to the area and allow investors to discover the site's potentials. Moreover, it involves the establishment of a database for terrestrial and underwater cultural heritage.

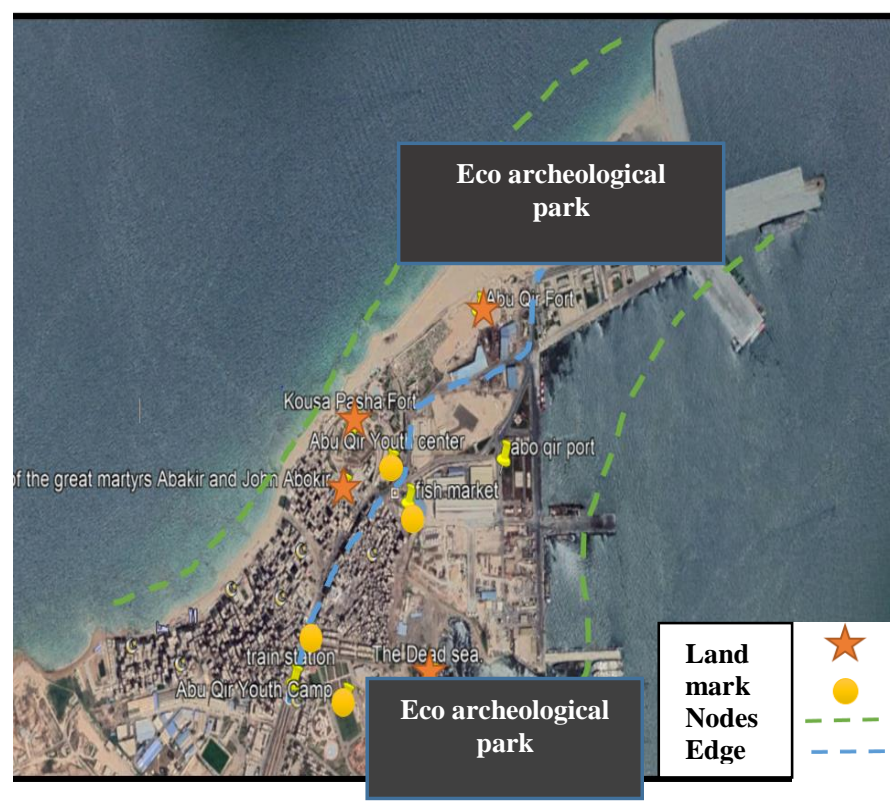

Figure 24. The archaeological parks proposal locations (Author).
The second stage is concerned with establishment two eco archaeological parks on two sites previously identified. Archaeological parks are aimed to connect urban spaces between land and sea. Furthermore, this stage involves the development of Abo Qir railroad (Fig.24)

The third stage is represented by the development of the areas that surrounded the archaeological sites through changing the land use on the waterfront, development of informal settlement, constructing great tourist attractions, and connecting the site with Alexandria tourist route. Moreover, this stage involves the construction of an underwater archaeology centre, archaeology school, and underwater trail that contacting between Abo Qir submerged sites and Montazah submerged ruins (Fig.25, 26).

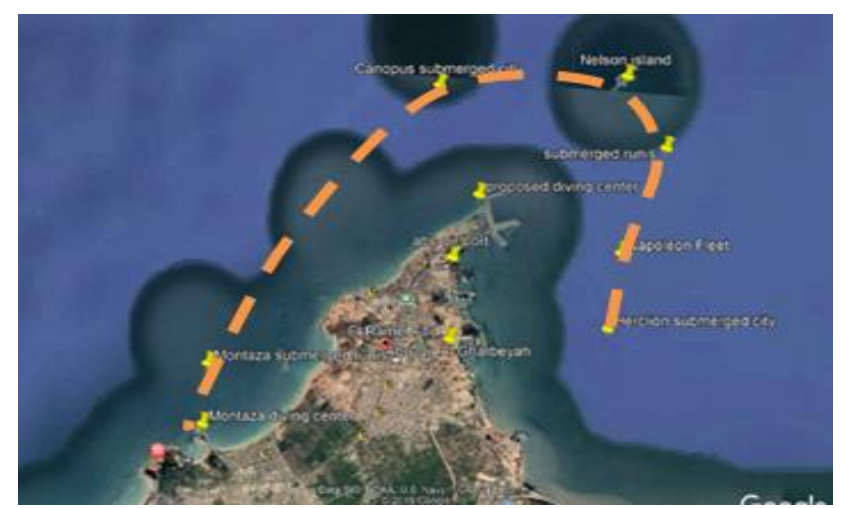

Figure 25. The underwater archaeological trail (Author). 


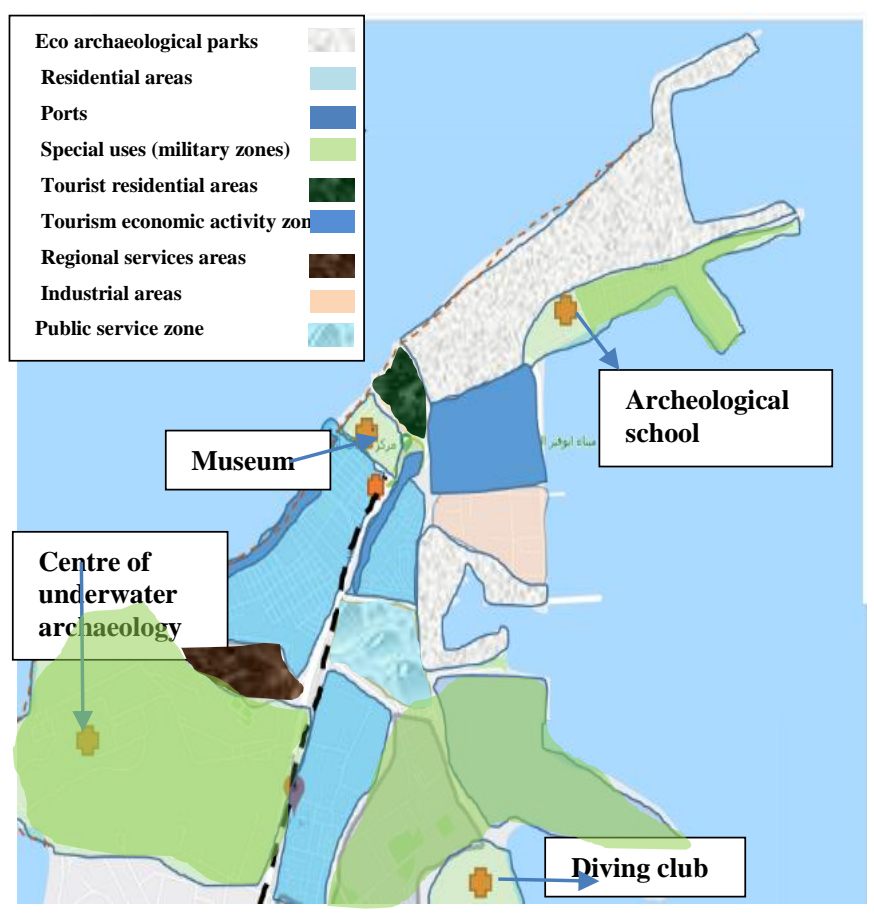

Figure 26. The proposal land use (Author).

\section{b. The social vision}

The Community is an important element of the sustainable conservation and good planning for heritage sites conservation. (Fig.27) shows the proposed aspects for improving public access and awareness of conserving heritage sites in Abo Qir.

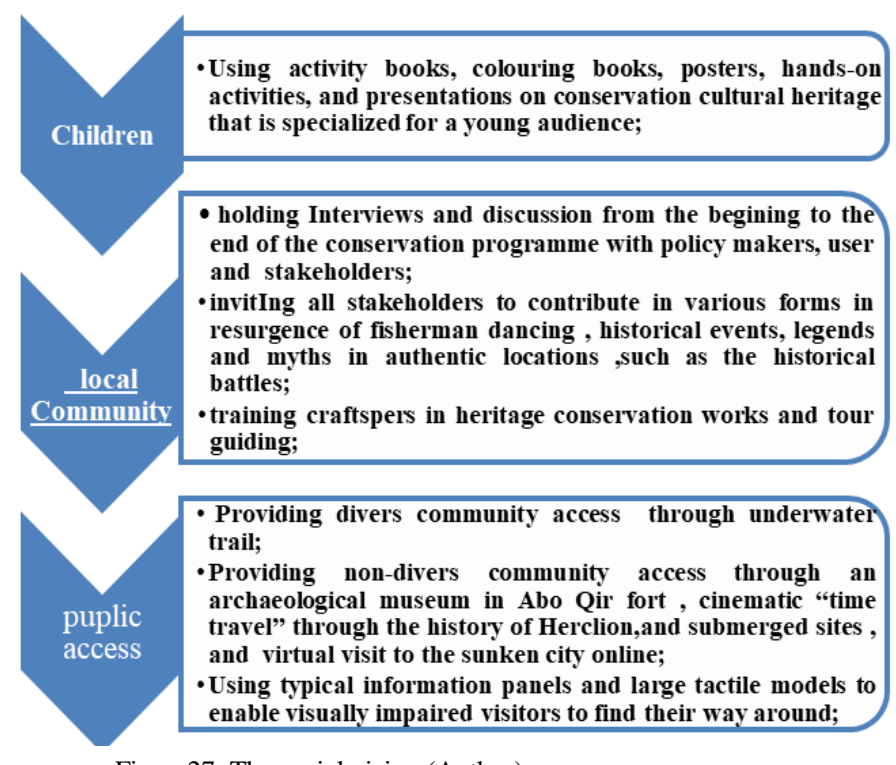

Figure27. The social vision (Author)

\section{c. The environmental vision}

The environmental vision will be based on providing sustainable and healthy environment in Abo Qir. Furthermore, all the stakeholders will involve in the environment protecting and managing activities, such as treatment the bay from the sewage, industrial wastes, and improving the infrastructure.

Moreover, all objects in the streets, squares, and the public urban spaces will be built by using the recycled materials, wood and other eco materials. Besides, the public lighting will be powered by the solar energy, and the different modes of environmental friendly transportation, such as boats, bikes, and horse cart will be used to access the waterfront.

The programme will be worked in improving the concept of eco archaeological parks that include a range of sustainable and restorative uses related to organic agriculture, aquaculture, biotechnology, and access the submerged sites. Moreover, the waterfront landscape elements will be used to resist the coastal erosion [27] (Fig.28).

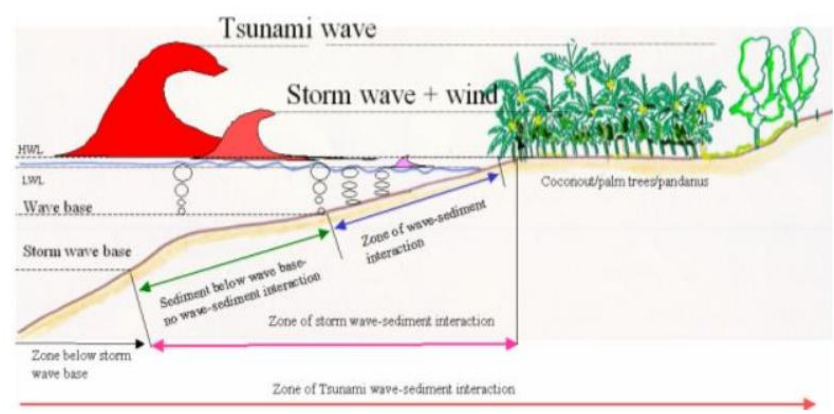

Figure28. Protective function of coastal forests and tress. [27]

\section{d. The economic vision}

The main idea of the economic development of this area to become an important heritage touristic pole that adds to the feature of Alexandria, and its submerged ruins.

In addition, this concept is concerned about rising the value of Abo Qir as a generators of revenue, jobs and training opportunities, that lead to improve the residents incomes from cultural heritage conservation activates, such as tour guiding, diving training, restoration works, etc.

The proposed programme will be worked in securing funding for conservation programme. This funding will base on all stakeholders, such as residents, government, and different organizations. The government will secure strategic public investment in the infrastructure while the municipalities will regulate and restrict land use transformation, and shift the activities that may harm the historical context. Furthermore, residents will participate through equity financing, advances, loans, and voluntary conservation activities etc.

\section{Questionnaire results}

The questionnaire was designed based on the key factors of the sustainable conservation. It was divided into three sections:

(1) Personal information on the participants; (2) the interesting of the participants in the conservation of the submerged cities;(3) evaluating the proposed conservation projects for sustainable conservation and development;

The third section requested that participants to mark the effect of the proposed project from the most to the least effect in terms of three levels: high, medium, and low effect.

The survey included (104) person who were divided into two groups of people

1-Those who are vitally depend on the studied area (live or work there).2-Occasional visitors (tourists and alike).

The results from the questionnaire can be summarized as follow: 
Urban dimension

The participant's responses show that the proposed project have a significant effect on providing some goals more than others do, and these goals are arranged as follow:

1-Increasing sense of safety, and belonging;

2- Upgrading informal human settlements and slums;

3- Conservation of the local identity;

4- Providing universal access to Abo Qir waterfront;

5-Improving urban management;

6- Improving infrastructure and public service (Fig.29);

Economic dimension

The survey show that the proposed project goals have a significant effect on providing some goals more than others do, and these goals are arranged as follow:

1-Provision youth employment;

2- Provision sustainable tourism;

3- Provision sustainable economic growth;

4- Poverty reduction and social justices (Fig.30);

Social dimension

The survey show that the proposed project goals have a significant effect on providing some goals more than others do, and these goals are arranged as follow:
1-Increasing social cohesion and public awareness on conservation cultural heritage;

2- Ensure inclusive and participatory- decision making;

3- Community capacity building;

4- Provision community partnerships (Fig.31);

Environmental dimension

The survey show that some proposed projects have a high effect on conservation environment more than others do and these projects are arranged as follow:

1-Establishment eco- parks on the waterfront;

2- Using renewable energy;

3- Providing cyclist routes in the street design;

4- Organising workshops on conservation natural and marine environment;

5- Using recycled materials in the construction;

6-Using environmental friendly transportation, such as boats, and horse cart (Fig.32); these responses reflect the low public awareness in the importance of the green modes of transportation in conservation the environment. In addition, these responses reflect their needs to high quality green areas in the waterfront urban spaces.

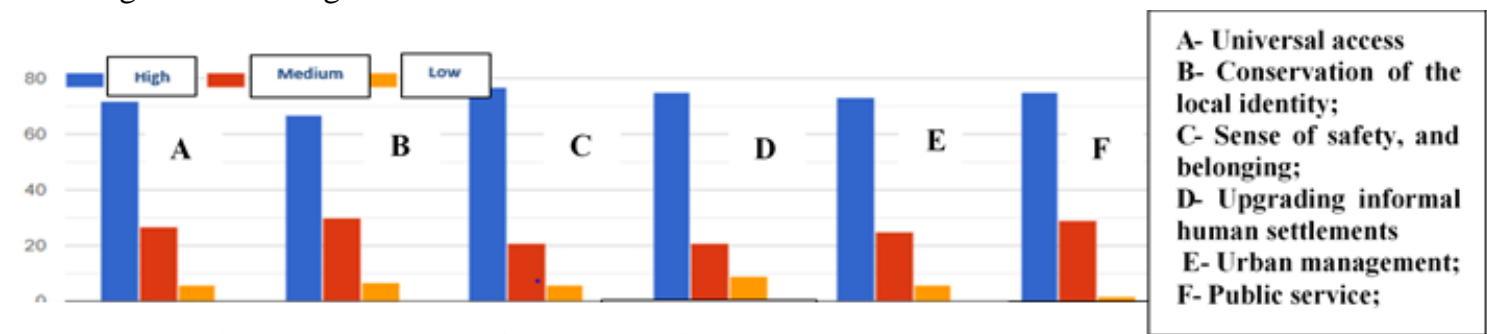

Figure 29. Economic sustainable conservation goals (Author).

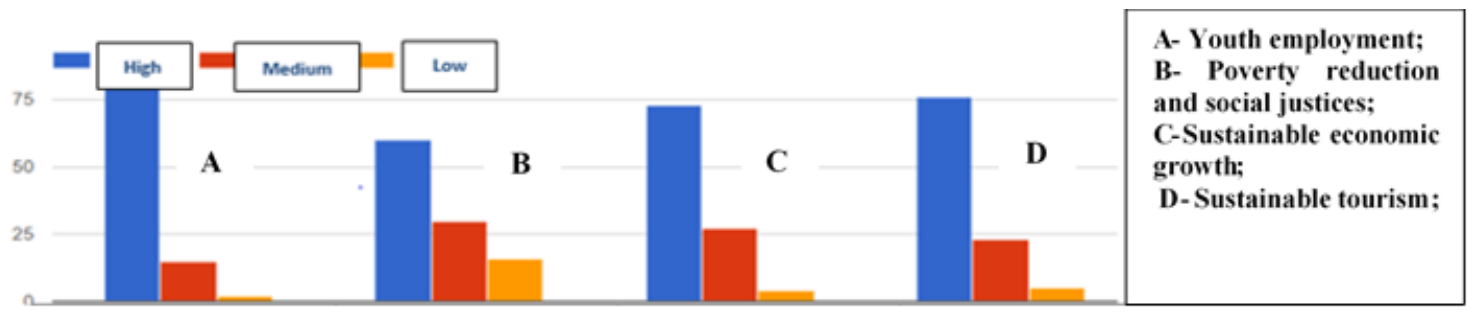

Figure 30. Economic sustainable conservation goals (Author).

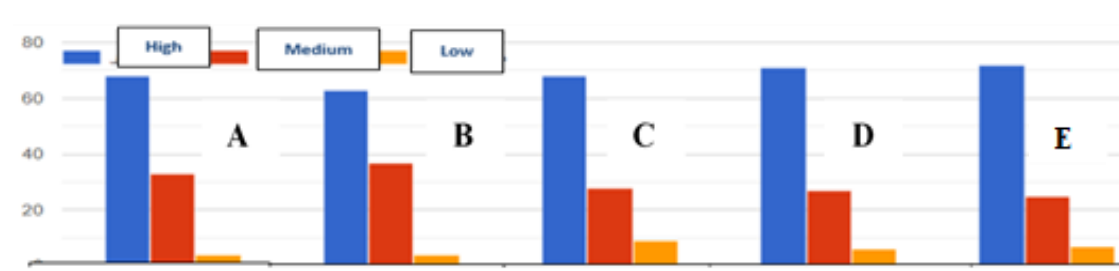

Figure31. Social sustainable conservation goals (Author).

A-Community capacity building;

B-Community

partnerships;

C-participatory-decision

making;

D- Public awareness;

E- Social cohesion;

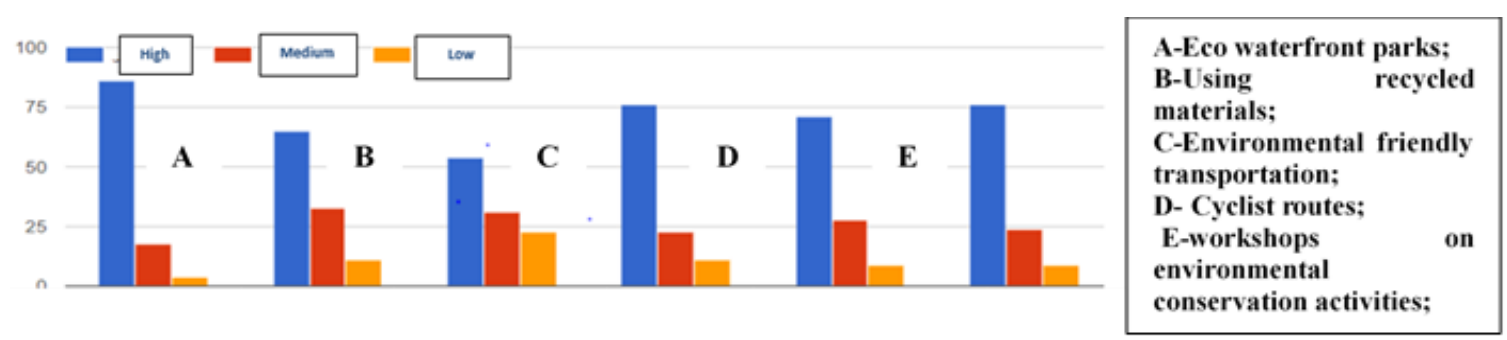

Figure 32. Environmental sustainable conservation projects (Author). 


\section{DISCUSSION}

Coastal and the submerged archaeological sites in Abo Qir, such as Herclion consider as one of the worldwide significance sites and they represent an important tourism resource for the country, However, they are threatened by unplanned urban development, sea level rise, and low public awareness.

This study proposed a framework to assist decision makers in conservation terrestrial and underwater heritage sites in Abo Qir and determining the most effective measures to conservation this unique form of cultural heritage. The framework starting with an overview of the submerged city and its waterfront. Then it presented SWOT analysis of the functions of the waterfronts and Herclion that lead the researcher to conclude some strategies to conservation these unique sites, finally the study is proposed some projects that were identified by $\mathrm{UCH}$ and urban experts.

The survey results show that the concept of reconnecting Abo Qir waterfront with Herclion through Eco- archaeologic park, and series of view corridors toward the waterfront that include underwater archaeology centre, archaeology school, and archaeologic trails that provide connection between terrestrial and underwater heritage sites along the waterfront have a high effect in upgrading the waterfront urban spaces and historical forts, improving the local economy, sense of identity, provide public awareness on conservation cultural heritage sites. Its worthy to note that all of these conservation measures require dedicated public awareness and participation between all stakeholders. These concepts were applied in the previous international experiments in conservation of the submerged cities, such as Baia in Italy.

\section{CONCLUSION}

The link between conservation submerged city and sustainability is a relatively new one. Over years, Hercalion and its waterfront are faced neglect and deterioration. Additionally, the responsible parties in Abo Qir and Alexandria are uninterested in conservation this unique site. This study proposes a framework for providing a sustainable conservation. This framework is concentrated on the conservation of marine and natural environment of Abo Qir Bay, conservation of underwater and onshore cultural heritage sites, building the community capacity in conservation activities, and enhancing economic development. Furthermore, it integrates all of these factors in the waterfront development process as an interaction urban point between submerged city and its waterfront. Furthermore, a questionnaire survey that has been token in Abo Qir residents show that the proposed conservation framework has a significant effect on providing long term of sustainable conservation measures for this unique site.

The wider issue of the sustainable conservation in Abo Qir is that the harnessing of the cultural heritage sites in Abo Qir waterfront in urban conservation projects require a participation between all stakeholders especially, the military parties. Also, the waterfront forts provide an important element of the sustainable conservation. The uses of Abo Qir forts as an eco-archaeological parks are considered as the key to provide a long term of conservation for this unique city and its waterfront.

\section{REFERENCES}

[1] Scovazzi, T. (2002). Convention on the protection of underwater cultural heritage. Envtl. Pol'y \& L., 32, 152.

[2] http://www.unesco.org/new/en/culture/themes/underwater-culturalheritage/underwater-cultural-heritage/ruins-caves-and-wells/. Accessed (34-2020).

[3] Perez-Alvaro, E. (2016). Climate change and underwater cultural heritage: Impacts and challenges. Journal of Cultural Heritage, 21, 842-848.

[4] http://www.unesco.org/new/en/culture/themes/underwater-culturalheritage/underwater-cultural-heritage/ruins-caves-and-wells/. Accessed (116-2020).

[5] Tawab, A. A. (2014). Sustainable conservation and the inherent qualities of the traditional community in Taos Pueblo in the United States of America.

[6] Aref, Y. G. E. D.(2009). The Conservation of Heritage as a Means for Sustainability, The Case of the Ottoman Town, Alexandria, Egypt.

[7] Maarleveld, T. J., Guérin, U., \& Egger, B. (Eds.). (2013). Manual for activities directed at underwater cultural heritage: Guidelines to the annex of the UNESCO 2001 convention. Unesco.

[8] Chen, C. H. (2015). The analysis of sustainable waterfront development strategy-The case of Keelung Port City. International Journal of Environmental Protection and Policy, 3(3), 65-78.

[9] https://www.theguardian.com/science/2015/aug/02/ancient-egyptianartefacts-thonis-heracleion-canopus-paris/. Accessed (1-16-2020).

[10] https://www.gounesco.com/egyptian-underwater-heritage-inalexandria-and-preservation-management.Accessed (1-16-2020).

[11] Hamouda, A., El-Gendy, N., El-Gharabawy, S., \& Salah, M. (2015). Acoustic Survey along Heraklieon and East Canopus Ancient Greek Cities, Abu Quir Bay, Alexandria, Egypt. Journal of Earth Science \& Climatic Change, 6(7).

[12] http://www.cubadebate.cu/noticias/2013/12/13/arqueologosencuentran-ciudad-egipcia-sepultada-por-el-mediterraneo/\#.XiBGwcgzZPY. Accessed (1-16-2020).

[13] Elnokaly, A., Elseragy, A., \& Gamal, M. (2008). A proposal for an ecological park towards a sustainable humane habitat in Abu Qir, Alexandria, Egypt. International Conference on Humane Habitat (ICHH).

[14] Abdel- Salam, H. (1995). The historical evolution and present morphology of Alexandria, Egypt. Planning Perspectives, 10(2), 173-198.

[15] Morcos, S., El-Abbadi, M., Awad, H., Halim, Y., \& Tongring, N. (2003). Towards integrated management of Alexandria's coastal heritage.

[16] Abd-el-Maguid, M. M. (2012). Underwater Archaeology in Egypt and the Protection of its Underwater Cultural Heritage. Journal of Maritime Archaeology, 7(1), 193-207.

[17] El-Kady, M. (2017). Potentials of Underwater Cultural Heritage in Tourism from the Perspective of Tour Guiding in Alexandria, Egypt. Tourism Research Institute,

[18] https://news.un.org/en/story/2008/09/271782-unesco-backs-planbuild-underwater-museum-alexandria-egypt. Accessed (16-1-2020).

[19] Sharaf El Din, S., Fekry, F., \& El Menchawy, A. (2013). Abu Qir fortresses as vital assets for tourism motivation and community development. Wiadomości Konserwatorskie.

[20] Central Agency for Public Mobilization and Statistics (CAPMAS). (2019). Statistical Year Book.

[21] Central Agency for Public Mobilization and Statistics (CAPMAS). (2017). Statistical Year Book.

[22] Central Agency for Public Mobilization and Statistics (CAPMAS). (2006). Statistical Year Book.

[23] https://en-gb.topographic-map.com/maps/lprq/Alexandria/ . Accessed (1-10-2020)

[24] Elbisy, M. S. (2016). Environmental management of offshore gas platforms in Abu Qir Bay, Egypt. KSCE Journal of Civil Engineering, 20(4).

[25] https://www.franckgoddio.org/projects/sunkenivilizations/heracleion.html.Accessed (1-11-2020)

[26] http://www.dailymail.co.uk/sciencetech/article7281351/Archaeologists-discover-sunken-ancient-settlementunderwater.html.Accessed( 11-11-2019) 
[27] https://www.theguardian.com/cities/2016/aug/15/lost-cities-6thonis-heracleion-egypt-sunken-sea (23-6-2019)

[28] Mostafa, M. H., Grimal, N., \& Nakashima, D. (2000). de l'article/du chapitre Underwater archaeology and coastal management: focus on Alexandria. distributeur UNESCO Publishing.

[29] Adam, A. M. S. (2015). Stock Assessment and Management of Diplodus Species In Abu Qir Bay, Alexandria, Egypt (Doctoral dissertation)

[30] http://www.fao.org/3/AG127E09.htm.. Accessed (1-16-2020)

\section{THE APPENDIX}

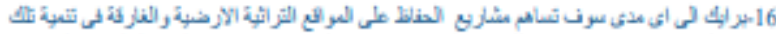

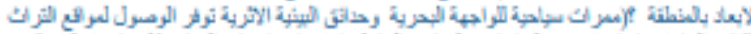

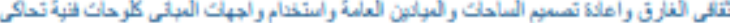

\begin{tabular}{|c|c|c|c|}
\hline تصنيت & in & 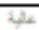 & \\
\hline & & & 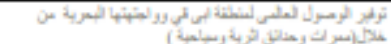 \\
\hline & & & 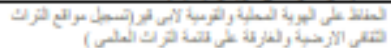 \\
\hline & & & 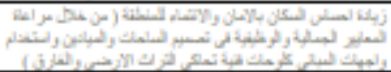 \\
\hline & & & I \\
\hline & & & 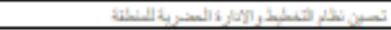 \\
\hline & & & 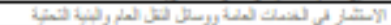 \\
\hline
\end{tabular}

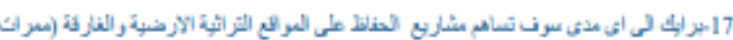

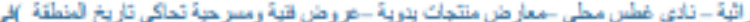

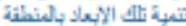

\begin{tabular}{|c|c|c|c|}
\hline ضمبنة & 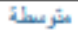 & 519 & \\
\hline & & & 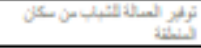 \\
\hline & & & 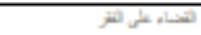 \\
\hline & & & 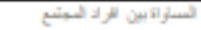 \\
\hline & & & 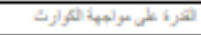 \\
\hline & & & 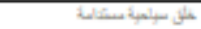 \\
\hline & & & 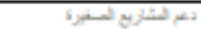 \\
\hline & & & 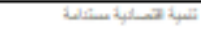 \\
\hline & & & 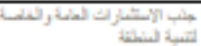 \\
\hline
\end{tabular}

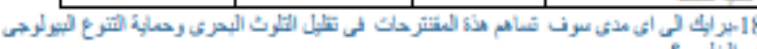

\begin{tabular}{|c|c|c|c|}
\hline عising & شتربطة & 8 & \\
\hline & & & 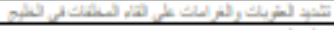 \\
\hline & & & 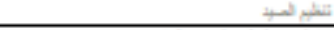 \\
\hline & & & 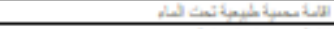 \\
\hline & & & 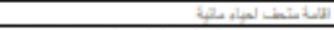 \\
\hline & & & 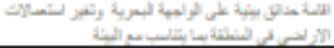 \\
\hline & & & 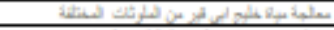 \\
\hline & & & 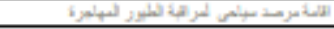 \\
\hline & & & \\
\hline
\end{tabular}

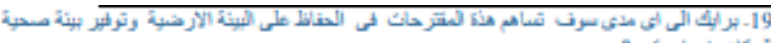

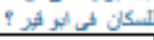

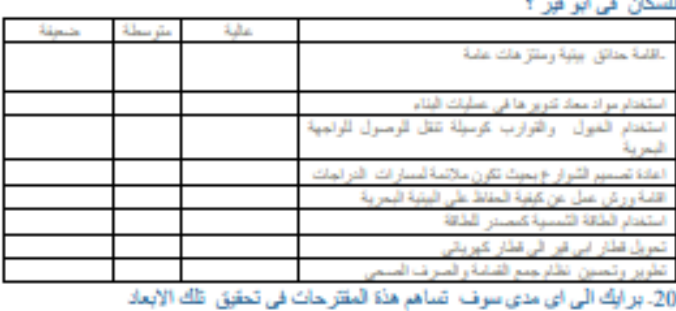

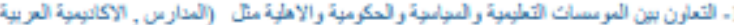

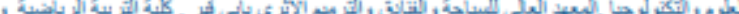

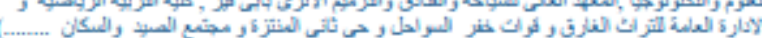

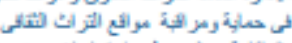

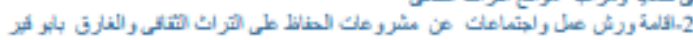

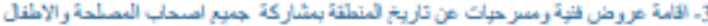

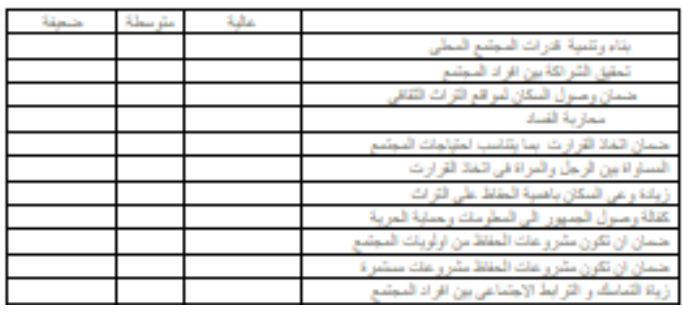

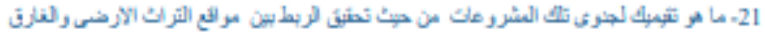

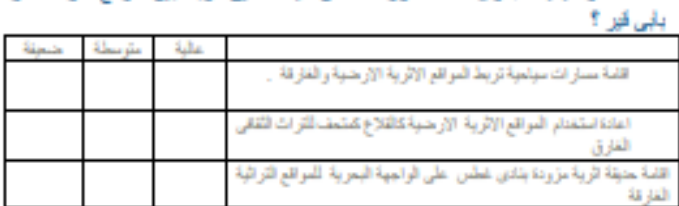

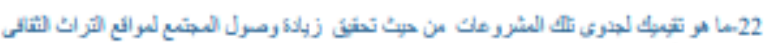

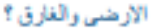
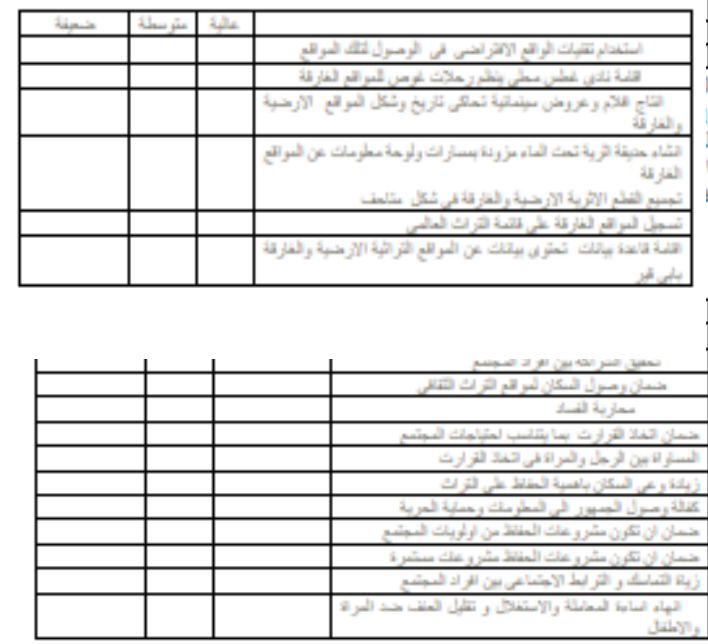